\title{
A juvenile filarial worm, Wuchereria bancrofti, extracted from the vitreous of the eye: the first report in the world literature
}

\section{Sagarika Samarasinghe ${ }^{1}$ and Saliya Pathirana ${ }^{2}$}

(Index words: Filarial fluorescent antibody test, vitrectomy)

\section{Summary}

A live worm was extracted from the vitreous of the eye of a patient in Sri Lanka. Based on the details of its length, width, oesophagus and vulva it was identified as a juvenile female Wuchereria bancrofti.

\section{Introduction}

Wuchereria bancrofti has been reported from the anterior chamber of the eye from three patients worldwide [1-3] but not from the vitreous. This is the first time that a female Wuchereria bancrofti has been found in the vitreous of the eye.

\section{Case report}

In February 2003, a 46-year old woman from the Southern Province of Sri Lanka, presented to the Eye Hospital, Colombo with a complaint of a moving object in the left eye for 6 months causing irritation. She was not suffering from any other systemic or local manifestations. The full blood count showed polymorphonuclear leucocytosis with no eosinophilia. The filarial fluorescent antibody test was weakly positive and the filarial antigen test was negative.

Her right eye vision was $6 / 6$ and the left eye vision was $6 / 12$. Intra-ocular examination revealed a wriggling pale, motile worm in the vitreous of the eye. Under local

Table1. Details of the Wuchereria bancrofti worms extracted from the human eye

\begin{tabular}{lcccc}
\hline $\begin{array}{l}\text { Description } \\
\text { of worm }\end{array}$ & $\begin{array}{l}\text { Samara- Bain } \\
\text { singhe } \\
\text { et al. }\end{array}$ & $\begin{array}{l}\text { Gautriet } \\
\text { et al. }\end{array}$ & $\begin{array}{l}\text { Fernando } \\
\text { SE }\end{array}$ \\
\hline Length $(\mathrm{mm})$ & 13 & 10.4 & 45 & 90 \\
Width $(\mu \mathrm{m})$ & 100 & 105 & 160 & - \\
Nervering $(\mu \mathrm{m})$ & 100 & 175 & 230 & - \\
Oesophagus $(\mu \mathrm{m})$ & 900 & 1100 & 1510 & - \\
Vulva $(\mu \mathrm{m})$ & 450 & 460 & 830 & - \\
Tail $(\mu \mathrm{m})$ & 120 & 165 & 220 & - \\
Site & vitreous & ant.cha.* & ant.cha.* & ant.cha.* \\
\hline
\end{tabular}

*anterior chamber anaesthesia vitrectomy was performed on the left eye. An intact live worm was recovered from the vitreous. The patient became symptom free subsequently. Details of the worm are summarised in the Table 1.

\section{Description of the worm}

The worm was minute and thread-like in form with a smooth cuticle. Although tapering towards both ends, the terminations were bluntly rounded. The head was slightly swollen (Figure 1). The length of the worm was $13 \mathrm{~mm}$ and the width $0.1 \mathrm{~mm}$. The nerve ring was situated $100 \mu \mathrm{m}$ from the anterior end. The length of the oesophagus was $900 \mu \mathrm{m}$. The vulva was situated $450 \mu \mathrm{m}$ from the cephalic end and was anterior to the oesophagus. The length of the tail was $120 \mu \mathrm{m}$. These details are compatible with a juvenile female Wuchereria bancrofti worm.

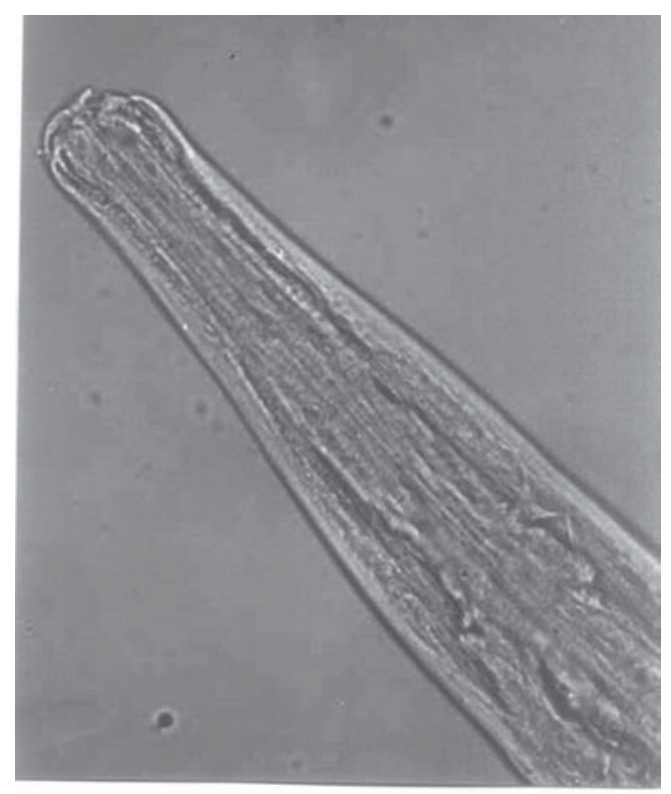

Figure 1. Head of the worm.

\section{Discussion}

There are three previous reports of filarial worms recovered from the anterior chamber of the eye of the

${ }^{1}$ Medical Parasitologist and Head, Department of Parasitology, Medical Research institute and ${ }^{2}$ Opthalmic Surgeon, Eye Hospital, Colombo, Sri Lanka.

Correspondence: SS, e-mail: <samasagarika@hotmail.com>. (Competing interests: none declared). Submitted 15 February 2005 and revised version accepted 12 September 2005. 
patients worldwide, but not from the vitreous [1-3]. There are reports about nematodes extracted from the vitreous of humans, such as hookworm [4], Dirofilaria immitis [5] and Parastrongylus spp. [6] from Sri Lanka and other parts of the world but no case reports are available of Wuchereria bancrofti.

Therefore this is the first record of a Wuchereria bancrofti from the vitreous of a human in the world. The features of the worm in this case closely resemble the measurements of a female Wuchereria bancrofti [1].

We can only speculate how this worm gained access to the vitreous. The worm may have come through either the blood stream to the choroid and then to the vitreous, or from the anterior chamber to the posterior chamber and through the ciliary body into the vitreous.

\section{Acknowledgements}

We thank Professor AS Dissanaike for his advice, Dr. KA Zalvin, Registrar, Eye Hospital, Colombo, Mrs RADN Jayanthi, Photography unit, Postgraduate Institute of Medicine, Mrs CS Surige and Mr RAJC Jayasinghe, Department of Parasitology, Medical Research Institute for their co-operation.

\section{References}

1. Bain O, Kusaladharma PIT, Weerasooriya MV, Ihalamulla R, Dissanaike AS. An immature filarial worm, probably Wuchereria bancrofti, from the anterior chamber of the eye in a patient from Sri Lanka. Parasite 2002; 9: 282-4.

2. Gautret P, Bain O, Gicquel JJ, Hue B, Kauffmann-Lacroix $\mathrm{C}$, et al. Localisation sous-conjunctivale d'une femelle adulte de Wuchereria bancrofti. Bulletin de la Societe de Pathologie Exotique et de ses filiales 1999; 52: 104-6

3. Fernando SE. Ocular filariasis: Adult Wuchereria bancrofti in the anterior chamber of human eye. Journal of Tropical Medicine and Hygiene 1935; 38: 17-8.

4. Dissanaike AS, Ihalamulla RL, Daya de Silva, Saliya Pathirana, Udaya Weerakoon, et al. On a dead female hookworm, probably Ancylostoma tubaeforme, from the vitreous of a patient in Sri Lanka. Ceylon Journal of Medical Sciences 2000; 43: 25-30.

5. Dissanaike AS, Ramalingam S, Fong A, Pathmayoken S, Thomas V, et al. Filaria in the vitreous of the eye of a man in peninsular Malaysia. American Journal of Tropical Medicine and Hygeine 1997; 26: 1143-7.

6. Durette-Desset MC, Chabaud AG, Cassim MHS, Ismail MM, Premaratne UN, et al. On an infection of a human eye with Parastrongylus (=Angiostrongylus) sp. in Sri Lanka. Journal of Helminthology 1993; 67: 67-71. 